\title{
Determining the Fears of Student with Special Needs in Inclusive Environments
}

\author{
Osman ÖZOKÇU ${ }^{1} \&$ Taşkın YILDIRIM ${ }^{2}$ \\ ${ }^{1}$ Department of Special Education, Faculty of Education, Inonu University, Malatya, Turkey \\ ${ }^{2}$ Department of Educational Sciences, Faculty of Education, Inonu University, Malatya, Turkey \\ Correspondence: Osman ÖZOKÇU, Faculty of Education, Inonu University, Malatya, Turkey. E-mail: \\ ozokcu@gmail.com
}

Received: January 29, 2018

Accepted: March 7, 2018

Online Published: May 29, 2018

doi:10.5539/ies.v11n6p174

URL: https://doi.org/10.5539/ies.v11n6p174

\begin{abstract}
This study aims to determine and identify the fears of students with special needs in inclusive classrooms. The study was conducted with a total of 69 students (32 female, 37 male) from 36 classrooms across 12 different schools (including six primary schools and six middle schools) in Malatya, Turkey. The data were collected using a semi-structured interview technique and analyzed through descriptive analysis technique. These results revealed that students feared animals, spiritual associations, being negatively evaluated by figures of authority and other students, harm and suffering, death and loss, being subject to violence, and natural events and phenomena.
\end{abstract}

Keywords: inclusion, children's fears, students with special needs

\section{Introduction}

Schools are among the most important professional institutions when raising healthy individuals. Schooling rates and educational environments are important determinants of individuals' success in both developed and developing countries. School changes from being an abstract concept to a concrete idea when considered as part of a larger system, one that includes buildings, teaching and administrative staff, auxiliary staff, and students, the primary component.

Starting school is an important period for children as it is often their first experience of a long-term separation from their family, as well as their first independent with the outside world. Schools, in a sense, serve as a shelter for children once they have left their parents. When a child attends school for the first time teachers enter the child's world as a new adult, one that will influence them in the future, and potentially even as much as their parents. Establishing a warmhearted relationship with teachers is critically important for children regarding their future educational lives. Formal education, therefore, serves a purpose beyond that of equipping children with academic skills, and has a primary role in teaching children social skills in preparation for their futures. As expected and hoped for, a clear majority of children experience the school adaptation process in a healthy manner; for some children, however, the school remains a continuous source of anxiety. Experts describe starting school as the 'second separation' of a child from its mother, and first since the child's birth. This 'second separation' can be a stressful period for some children (Özcan \& Aysev, 2009; Sarp, 1995).

Children may experience depression in a similar way to adults. Recent community surveys and clinical experiences have also revealed that that depression is as prevalent among children as it is among adults. Depression, languishment, unwillingness, unwillingness to play games, unwillingness to attend school, eating and sleeping disorders, hyperactivity, moodiness, indocility, and behavioral disorders are symptomatic of anxiety disorders in children. In some cases, it can be seen with physical symptoms such as stomachache, nausea, and arthralgia (Öztürk, 2006; Erdoğan, Tamar, \& Erdoğan, 2002; Kaya, Özcan, \& Kaya, 2006).

Some studies on the psychological problems seen in childhood and adulthood have determined that anxiety disorders - such as separation anxiety and scolionophobia - when experienced in childhood, are symptomatic or indicative of social-phobias and panic disorders in adulthood. For this reason, early diagnosis and intervention regarding psychological problems encountered during an individual's childhoods are important for the community as well as individual health (Dilbaz, 1997; Sevinçok, 2000; Öztürk, 2001; Y1ldız, 2008). One important demographical group who demand a different investigation regarding the development and experience of 
psychological disorders in the childhood period in either a specialized or normal educational environment; this group includes those children with special needs.

Throughout the second half of the $20^{\text {th }}$ century, the importance of educating students with special needs in the least restrictive environment possible - that is, in similar environment to those children without special needs - has resulted in the development of what are known as 'inclusive environments' (Batu \& Kırcaali-İftar, 2005; Lewis \& Doorlag, 2003; Kırcaali-İftar, 1992; Sucuoğlu, 2006). Inclusion can be described as a service model that provides opportunities by which to educate children with special needs alongside their peers; that is, students without special needs (Lewis \& Doorlag, 2003; Sucuoğlu, 2006). According to the inclusion model, students with special needs are educated in general education classrooms by general education teachers; therefore, children with special needs spend their school day and have their educational needs fulfilled in a normal classroom environment among their peers. The main purpose of inclusive programs is to help students with special needs become active members of their classrooms and interact socially with students without special needs within a single educational environment - thereby leading to an increase in their social acceptance (Sazak, 2003; Sucuoğlu, 2006). In addition to these main purposes, a further aim for inclusive programs is that children with special needs will benefit from general curricula and be provided with opportunities for participation throughout all stages of their school life (Heiman \& Margalit, 1998; Sucuoğlu, 2006; Sazak-Pınar, 2008). An investigation as to whether inclusive education fulfills these purposes is needed; this investigation can be achieved by considering the inclusive education practices and monitoring students with/without special needs in inclusive environments. Using the analysis results, measures can be taken to increase the effect and success of inclusive programs.

Inclusive environments provide unique learning opportunities for children with special needs, educating them in the same environment as typically developing children (Salend, 1998; Akçamete \& Ceber, 1999). These relationships have positive effects on the achievement and social interactions of students with special needs (Lewis \& Doorlag, 2003; Sucuoğlu, 2006). Despite the positive effect these inclusive practices on students with special needs, some studies have revealed that students with special needs are sometimes rejected from in inclusionary classrooms, or else experience difficulties being accepted among their non-special needs peers (Larrive \& Horne, 1991; Salend, 1998, Akçamete \& Ceber, 1999). The question regarding the dynamics of not being accepted or being rejected by an individual or a group of individuals is as old as human social interaction itself. Since humans have existed they have struggled their own, often dominating, nature; this struggle has become a necessity for maintaining life and surviving. Experienced sometimes success or sometimes failures in this struggle process, humankind has resumed becoming dominant every time. During the struggle with nature, humankind is sometimes desperate against nature and obscurities, and experience panic and fear. Panic and fearful experiences have brought people together, and facilitated socialization; socialization is the organizational outcome of humans using the trust to counteract their own nature. People who have socialized gradually have either undertaken an aggressive attitude toward the initial event that desperate (sometimes to individuals different from them), withdraw, or figure out ways to cope (Yildırım, 2006). Consequently, it can be seen how anxieties act as decisive resources determining both what people can and cannot do as well as containing information as to what they have and have not done in the past.

Freud (1917) made a distinction between real and unreal fears and identified unreal fears with anxiety. Therefore, fear is a particular kind of skill used for envisioning and for comprehension while anxiety is a type of emotion. Consequently, fear can be seen as real and objective, indeed an independent observer would be able to accept a fearful situation as one entailing danger. Anxiety, on the other hand, is generally an emotion that is experienced according to the phenomenological zone of the individual in question, and is not an objective nor a universal emotion. Under normal circumstances, fear serves as a warning to individuals against future and present dangers within their physical and social environments while also contributing to important and related functions regarding adaption and survival. In certain cases, however, an individual may experience excessive fear, and thereby choose to utilize an exaggerated adaptation mechanism in order to reduce the fear they experience. Exaggerated and inappropriate defense mechanisms can lead to abnormal behavior. Fear, anxiety, and phobic situations are especially important in the development - the past, present, and future experiences that shape an individual and their behavior-as they in some way determine what and how that person will avoid and approach certain phenomena and situations thereafter. This will also shape those unknown patterns that will determine that individuals' readiness and recourses concerning those issues in the future.

Childhood is traditionally seen as a happy period that many people fondly recall. Some observations indicate that this belief is not quite right, however, and throughout the childhood period, children tend to exaggerate their fears and anxieties that stem from problems they previously experienced. For example, a two-year-old child may become panicked when their mother leaves with a neighbor, and goes elsewhere. While short-term separations can 
create uneasiness, this can worsen as the period of separation increases. Consequently, anxiety disorders experienced in adult years often stem from fears and anxieties experienced during childhood (Yörükoğlu, 1980; Winnicott, 1998). Anxiety-based disorders prevailed among school-age children. These disorders are mostly diagnosed with symptoms of obsession, compulsion, depression, and trauma (Steiner, 2007). The school-age child is a term used to refer to children with and without special needs.

Contemporary Turkish studies on the problems encountered by students with special needs when learning via inclusive education practices are often limited to parents' and administrators' attitudes and perspectives. A few studies have investigated inclusive students' social skills, sociometric status, and loneliness level (Akçamete \& Ceber, 1999; Şahbaz, 2004; Sucuoğlu \& Özokçu, 2005; Baydık \& Bakkaloğlu, 2009; Bakkaloğlu, 2010). However, no study could be identified within the existing literature on the fears of students in inclusive education. For this reason, the current study is original as it aims to determine students' fears in inclusion education. It is expected that the findings of the current study will serve a basis for further research. This study aims to determine the fears of primary and elementary school special needs students in inclusive education.

\section{Method}

\subsection{Model of the Study}

The current study was conducted to determine fears of students with special needs in inclusive classrooms. Data were collected using the open-ended semi-structured interview technique as part of a qualitative research method (Yıldırım \& Şimşek, 2006).

\subsection{Participants}

In this study, sixty nine ( 32 girls \& 37 boys) students with special needs who are studying in 36 different inclusive classrooms from 12 schools (including 6 primary school \& 8 middle schools) have participated. A total of 69 special needs students with 36 learning disabilities and 33 mentally retarded students participated in this research. The study did not include special needs students from other disabled groups. All the demographic presented in Table 1.

Table 1. Participant demographics

\begin{tabular}{lccc}
\hline Variables & & $\mathrm{f}$ & $\%$ \\
\hline \multirow{3}{*}{ Gender } & Female & 32 & $46.37 \%$ \\
& Male & 37 & $53.62 \%$ \\
& Total & 69 & $100 \%$ \\
\hline \multirow{4}{*}{ Age } & 6-11 years & 36 & $52.17 \%$ \\
& 12-15 years & 33 & $47.82 \%$ \\
Grade level & Total & 69 & $100 \%$ \\
& 4th-5th grades & 22 & $31.88 \%$ \\
& 6th-8th grades & 21 & $30.43 \%$ \\
& Total & 69 & $100 \%$ \\
\hline
\end{tabular}

\subsection{Data Collection Tools}

An Information Form consisting of items on participants' demographics and a semi-structured information form was used to collect the data. In the interview form included the question: "What/Who do you most fear?"

\subsection{Data Collection}

All the study data were collected using one-to-one interviews; these interviews were conducted through the counseling services of participating schools. A simple implementation room, comprised of one table and two chairs, was prepared in each school. Participants were invited to the implementation room individually, where they chatted to boost their confidence, their volunteer participation was provided. Students' answers during the interviews were noted on the form by one of the researchers. After the interviews were completed they were transcribed verbatim and without alteration.

\subsection{Data Analysis}

This section describes the data analysis carried out in this study. First, descriptive analysis techniques were used to analyze qualitative data according to four: (1) Coding data, (2) Creating themes, (3) Arranging codes and themes, 
and (4) Identifying and interpreting results (Yıldırım \& Şimşek, 2006).

1) Coding data: The coding form used for the data analysis was prepared according to the essential principles of content analysis. The reliability of the coding was investigated by three experts in the field of inclusive education, who coded the data; the inter-coder reliability among the three coders was then investigated. The evaluations of the coders were seen to be very consistent with one another $(90 \%)$. When conducting a descriptive analysis of participants' data, participants' answer to the open-ended questions were assessed individually and a total of 52 different 'fear fields' were identified (e.g., dog, snake, monster, lighting, ghost etc.).

2) Creating themes: Subsequently, the researchers then read these codes repeatedly and tried to extrapolate and develop more general fear themes. After reading the transcriptions, a heading for each of the eight themes was determined. Three field experts then independently examined the interviews and reached a consensus on the appropriateness of the selected themes. The analyses show that a total of eight 'fear themes' or 'categories': fear of animals, fear of spiritual associations, fear of being negatively evaluated by figures of authority and other students, fear of harm and suffering, fear of death and loss, fear of being subject to violence, and fear of natural events and phenomena).

3) Arranging codes and themes: The researchers then descriptively analyzed the transcripts regarding the codes and themes that had been identified and created. As in the first two steps, all analyses were independently performed by the two research authors as well as three field experts to ensure the reliability of the descriptive analyses.

4) Identifying and interpreting themes: In the final step, the researchers interpreted and provided explanations and interpretations of their analyses to add meaning to the data collected, explain any cause-effect relationship concerning the data as well identifying and highlighting any relationships among the study results.

\section{Results}

The participants were coded as P1, P2, P3...P69, respectively. Direct excerpts from the interviews are included in this study; the researchers have used quotation marks, italics and intended paragraphs for the purpose of identification. When the students' answers to the semi-structured interview questions were analyzed and coded, a total of 52 fear codes and eight themes were identified; these eight themes are presented in Table 2.

Table 2. The themes and their short explanations

\begin{tabular}{ll}
\hline Theme & Explanation \\
\hline 1. Theme & Fear of animals \\
2. Theme & Fear of spiritual associations \\
3. Theme & Fear of being negatively evaluated by figures of authority and other students \\
4. Theme & Fear of harm and suffering \\
5. Theme & Fear of death and loss \\
6. Theme & Fear of being subject to violence \\
7. Theme & Fear of natural events and phenomena \\
8. Theme & Other fears \\
\hline
\end{tabular}

Data obtained from participant interviews were discussed and compared to related literature; the results of this discussion and the eight themes identified are seen in the following headings.

Theme 1: Fear of animals

On investigation of participants' answers for thematic fears, it was found that many students had named a specific animal; including snakes $(\mathrm{n}=12)$, scorpions $(\mathrm{n}=10)$, insects $(\mathrm{n}=8)$, and dogs $(\mathrm{n}=2)$. Participants expressed their views regarding their fear of animals as follows: "I fear snakes greatly" (P2), "I fear of scorpions" (P7), "I fear of big wild dogs" (P18), and "I fear of insects" (P27).

Theme 2: Fear of spiritual associations

Participants listed God, Azrael, demons, and jinn among their fears regarding spiritual associations. They expressed their views regarding the fears of spiritual associations as follows: "I most fear of God" (K4), "I very fear of Azrael" (K9), "I fear of demon" (K22), and "I fear that jinn scare me" (K23).

Theme 3: Fear of being negatively evaluated by figures of authority and other students

Regarding students' fears of being negatively evaluated by figures of authority and other students, participants 
expressed that they were most fearful of their fathers, principles, and police, as well as exams, ration cards, and low grades. Three of the participants fears their views regarding this issue as follows: "I most fear of my dad and the principle, and of having a low grade in my ration card" (P38), "I fear of my dad, my teacher and police, and of having a bad ration card" (K53), and "I most fear of my dad, principle, as well as having a bad ration card" (P62).

Theme 4: Fear of harm and suffering

On the assessment of students' fears of harm and suffering, participants expressed that they were fearful of getting lost, being poisoned, fires, cliffs, and having an injection. Five the participants expressed fears regarding this category as follows: "I most fear of getting lost" (P17), "I sometimes fear of being poisoned" (P28), "I fear of burning in a fire" (P36), "I fear of tumbling down the cliff" (P54), and "I fear of having an injection" (P66).

Theme 5: Fear of death and loss

According to their responses, students said that they feared death, receiving sad news, loss of a relative, and airplanes. Four participants expressed their fears as follows: "I fear death greatly" (P19), "I am very afraid of receiving bad news" (P34), "I am very fearful of death of my parents" (P42), and "I am fearful of plane crashes when I am on a plane" (P67).

Theme 6: Fear of being subject to violence

The students expressed that they were fearful of being beaten-up $(n=3)$, being slapped $(n=1)$, and bad people $(n=1)$. Five participants expressed their fears as follows: "I am very fearful of being beaten-up" (P6), "I fear being slapped" (P17), and "I am very fearful of encountering a bad person" (P60).

Theme 7: Fear of natural events and phenomena

Earthquakes, storms, flood, and nightfall were listed among participants' fears of natural events and phenomena. Five of the participants expressed their fears as follows: "I fear earthquakes" P11, "I fear storms" P12, "I fear sinking into a flood" P29, and "I fear nightfall" P44.

Theme 8: Other Fears

Among those fears that could not be classified under any other theme, participants listed fear of dreams, the apocalypse, scary movies, loneliness, and disabled individuals. Twelve participants expressed their fears as follows: "I fear dreams" P24, "I fear the apocalypse" P41, "I fear scary movies" P58, and "I fear loneliness" P61. In addition, the participants stated that they fear of getting a raw deal, children, disabled individuals, toys, crowd, and trucks.

The question "Who or what do you fear most?" was posed to students participating in this research; the frequencies and percentages of participants' answers are presented in Table 3.

Table 3. Frequencies and percentages of students' fears

\begin{tabular}{lll}
\hline Students' fears & $\mathrm{n}$ & $\%$ \\
\hline Fear of animals & 32 & 46.37 \\
Other fears & 12 & 17.39 \\
Fear of spiritual associations & 5 & 7.24 \\
Fear of harm and suffering & 5 & 7.24 \\
Fear of death and loss & 4 & 5.79 \\
Fear of being subject to violence & 4 & 5.79 \\
Fear of natural events and phenomena & 4 & 5.79 \\
Fear of being negatively evaluated by figures of authority and other students & 3 & 4.34 \\
\hline
\end{tabular}

Of the answers to the question "Who or what do you fear most?" presented in Table 3. As can be seen, 32 students had a fear of animals, five had a fear of spiritual associations, three had a fear of being negatively evaluated by figures of authority and other students, five had a fear of harm and suffering, four had a fear of fear of death and loss, four had a fear of being subject to violence, four had a fear of natural events and phenomena, and 12 students had fears of other things.

\section{Discussion, Recommendations, and Limitations}

This study investigated the fears of students with special needs in inclusive programs at a primary and elementary education level. Data for the study were collected using a semi-structured interview technique, and revealed that 
students with special needs were most fearful of animals, spiritual associations, being negatively evaluated by figures of authority and other students, fear of harm and suffering, death and loss, being subject to violence, and natural events and phenomena. These results corroborated the results of other literature studies (Lyness-Richard, 1997, Zulliger, 2000; Mercurio \& McNamee, 2008, Serim-Yıldız \& Erdur-Baker, 2013). Studies revealed that children between the ages of three and six were most fearful of animals, imaginary figures (ghosts, monsters, supernatural beings), scary beings, and natural events; children aged seven to eleven had more realistic fears such as physical injuries, health, natural events, school performance, robbery, being kidnapped, loneliness, and loss of their parents; that children between the ages of twelve and eighteen were most fearful of fear of violence, gangs, guns, and terrorist incidents. For example, Zulliger (2000) conducted a study on students' fears; 800 student participants (including 400 females and 400 males) were used in the study, which found that the most frequent student fears are animals, ghosts, jinn, scary dreams, darkness, people entering their home by force, and thunder. Similarly, Erol and Şahin (1995) conducted a study using children and adolescents aged 9-13; the study found that the most frequent fears among this group were death, loss of parents, God, hell, getting shot by a firearm, car or truck crashes, and being separated from their parents, in descending order of frequency among the study participants.

Existing studies on the fears of students with special needs present contradictory results. One group of researchers asserted that the fears of students with special needs and the fears of students without special needs were similar. In a further study conducted with 48 children and adolescent participants with mental disabilities, Ramirez, Nguyen, and Kratochwill (1998) found that children with mental disabilities more fearful of snakes, being killed, being kidnapped, home fire, medication, being injured, their loved people hurt by someone or something, guns, and strange sounds at night. Similarly, Ramirez and Kratochwill (1997) conducted a study with a total of 299 children aged 6-13 including 125 children with mental disabilities and 174 children without mental disabilities. They found that those participants with mental disabilities had more intense fears though the fears of both groups did not vary significantly. Being kidnapped, strangers, storms, and wars are among the fears both groups have in common.

Conversely, other studies have presented results that differ to those of the current (Gullone, King, \& Cummins, 1996; Li \& Morris, 2007). Gullone et al. (1996) conducted a study of 599 youths aged 7-18; participants were divided into two groups, those who had a mental disability and those who did not. The researchers reported that the group with mental disabilities had significantly higher fear scores compared to the group that did not. Furthermore, the study found that individuals with mental disabilities had similar fears to their younger peers who did not have a mental disability. The researchers booted that there were remarkable similarities between the responses of the two participant groups', though natural phenomena and animals were the most varied. Examples of these similarities include females having significantly higher fear scores than their male peers in both groups; however, males were most fearful of death and danger across both participant groups. Similarly, in their study Li and Morris (2007) highlighted that male individuals with learning difficulties and aged 14-18 had higher fear levels of than their peers of the same age who had no mental disability. Considering all these aforementioned studies, the participating children with special needs were selected from particular disability groups, and all special education schools or classes where no inclusive programs were carried out. As can be seen in the available literature, researchers in the field believe that this area of research demands more focus and a greater number of studies; therefore, it is inadvisable to make generalizations regarding extant studies' data and findings until available studies are increased in efficacy or number. The results of the current study suggest that further studies should be conducted with students with special needs in inclusive environments.

This research study has presented a description of its research findings according to the study participants - students with special needs at the developmental level of primary and elementary education. Based on the research discussion the research authors believe that psychoeducational research can be conducted on students' fear of animals as corroborated by the research findings and results. In particular research into the impact of fears of being negatively evaluated by figures of authority and other students on future personal development so that pedagogical arrangements can be undertaken to help students be more self-confident. Students' fear of spiritual associations might turn into guilt or obsession; and, as previously mentioned, pedagogical arrangements can be made to help them cope with these fears.

The research authors recommend inclusionary classroom teachers to consider the recommendations listed hereinbefore, and fulfill the essential elements - many of which play a crucial role regarding achievement in inclusive programs - such as noticing and evaluating students' needs, providing effective management and teaching practice based on the relevant curricula.

The researchers believe that future research in the field should focus on the fears of inclusion students with different diagnoses - this is, special education students with a disability other than that of slight mental 
impairment — and explore and investigate the source and nature of their fears. Further qualitative and quantitative studies can be conducted using different qualitative data-collection tools on the fears of primary and elementary school, high school and university students both with and without special needs, investigating the reasons for their fears and appropriate or possible coping methods.

This study has two main limitations. First, students with special needs who have personally benefitted from inclusive practices are assumed to be the best judge and most accurate source of information regarding their own fears. Based on this assumption the research was constructed and developed with the aim of recording participants' opinions regarding their own fears. A further limitation may arise from students experiencing difficulties in understanding and answering the questions put to them; however, it was thought that this limitation could be minimized or eliminated by selecting those students with the necessary skills to understand and respond to questions and expressing their feelings and thoughts. Secondly, participants of the current study predominantly had learning difficulties due to a slight mental disability, while no students from other disability groups were included herein. Consequently, this study was unable to investigate whether the students' fears varied across different disability groups.

\section{References}

Akçamete, G., \& Ceber, H. (1999).Kaynaştırılmış sınıflardaki işitme engelli ve işiten öğrencilerin sosyometrik statülerinin karşılaştırmalı olarak incelenmesi. Özel Eğitim Dergisi, 2(3), 44-74.

Bakkaloğlu, H. (2010). A comparison of the loneliness levels of mainstreamed primary students according to their sociometric status. Procedia Social and Behavioral Sciences, 2(2), 330-336. https://doi.org/10.1016/j.sbspro.2010.03.020

Batu ve Kırcaali-İftar, G. (2005). Kaynaştırma. Ankara: Kök Yayınları.

Baydık, B., \& Bakkaloğlu, H. (2009). Alt sosyoekonomik düzeydeki özel gereksinimli olan ve olmayan ilköğretim öğrencilerinin sosyometrik statülerini yordayan değişkenler. Kuram ve Uygulamada Ĕ̆itim Bilimleri, 9(2), 401-447.

Beck, T. A. (2005). Bilişsel Terapi ve Duygusal Bozukluklar (T. Özakkaş, Ed.). İstanbul: Litera Yayıncılık.

Dilbaz, N. (1997). Sosyal Fobi. Psikiyatri Dünyası, 1(1), 18-24.

Erdoğan, İ., Tamar, M., \& Erdoğan, E. (2002), Majör Depresif Bozukluk Tanılı Çocuk ve Ergenlerde Belirti Dağılımının Karşılaştırılması. Çocuk ve Gençlik Ruh Să̆lığı Dergisi, 9(3), 144-154.

Erol, N., \& Şahin, N. (1995). Fears of children and the cultural context: The Turkish norms. European Child and Adolescents Psychiatry, 4(2), 85-93. https://doi.org/10.1007/BF01977736

Freud, S. (1917). Mourning and Melancholia. The Standard Edition of the Complete Psychological Works of Sigmund Freud, Volume XIV (1914-1916): On the History of the Psycho-Analytic Movement, Papers on Metapsychology and Other Works (pp. 237-58).

Gullone, E., King, N., \& Cummins, R. (1996). Fears of youth with mental retardation: Psychometric evaluation of the Fear Survey Schedule for Children-II (FSSC-II). Research in Developmental Disabilities, 17, 269-284. https://doi.org/10.1016/0891-4222(96)00008-X

Heiman, T., \& Margalit, M. (1998). Loneliness, depression, and social skills among students with mild mental retardation in different educational settings. The Journal of Special Education, 32(3), 154-163. https://doi.org/10.1177/002246699803200302

Kaya, M., Özcan, Ö., \& Kaya, B. (2006). Malatya İl Merkezinde Farklı Sosyoekonomik Koşullardaki İlköğretim Okulu Öğrencilerinde Ruhsal Uyum Taramas1, Anadolu Psikiyatri Dergisi, 7, 157-161.

Kırcaali-İftar, G. (1992). Kaynaştırma becerileri öz-değerlendirme aracı. Anadolu Üniversitesi Eğitim Fakültesi Dergisi, 5, 119-129

Larrieve, B., \& Horne, M. D. (1991). Social status: A comparison of mainstreamed students with peers of different ability levels. The Journal of Special Education, 25(1), 90-101. https://doi.org/10.1177/002246699102500106

Lewis, L. B., \& Doorlag, R. B. (2003). Teaching special student in general education classrooms (6th ed.). Upper Saddle River, NJ: Merrill Prenctice Hall.

Li, H., \& Morris, H. J. (2007). Assessing fears and related anxieties in children and adolescents with learning disabilities and mild mental retardation. Research in Developmental Disabilities, 28, 445-457. 
https://doi.org/10.1016/j.ridd.2006.06.001

Lyness-Richard, D. (1997). Play therapy for children with fears and phobias. In H. Kaduson, \& D. Cangelosi (Eds.), The playing cure: Individualized play therapy for specific childhood problems. Child therapy series (pp. 29-59). Northvale, NJ: Jason Aronson, Inc.

Mercurio, M. L., \& McNamee, A. (2008). Monsters That Eat People-Oh My! Selecting Literature to Ease Children's Fears. Dimensions of Early Childhood, 36(2), 29-38.

Özcan, Ö., \& Aysev, A. (2009). Okul Fobisi Olan Çocuklarda Ruhsal Bozuklukların Sıklığının Araştırılması. İnönü Üniversitesi Tlp Fakültesi Dergisi, 16(1), 13-17.

Öztürk, M. (2006). 99 Sayfada Okul Fobisi, İstanbul: Türkiye İş Bankası Kültür Yayınları.

Ramirez, S. Z., Nguyen, T., \& Kratochwill, T. R. (1998). Self-reported fears in Hispanic youth with mental retardation: A preliminary study. Mental Retardation, 36, 145-156. https://doi.org/10.1352/0047-6765(1998)036<0145:SFIHYW $>2.0 . C O ; 2$

Ramirez, S., \& Kratochwill, T. R. (1997). Self-reported fears in children with and without mental retardation. Mental Retardation, 35, 83-92. https://doi.org/10.1352/0047-6765(1997)035<0083:SFICWA>2.0.CO;2

Salend, S. J. (1998). Effective mainstreaming: Creating inclusive classrooms (3rd ed.). Columbus, OH: Merrill/Prentice Hall.

Sarp, N, (1995). Öğretmenlerin İlkokula Başlayan Çocuklarda Gözledikleri Sorunlar ve Bu Sorunlara Yaklaşımları. Kriz Dergisi, 3(1-2), 129-132. https://doi.org/10.1501/Kriz_0000000116

Sazak, E. (2003). Zihin Engelli Birey İçin Hazırlanan Akran Aracıll Sosyal Beceri Öğretim Programının Etkiliğinin İncelenmesi. Yayımlanmamış yüksek lisans tezi, Abant İzzet Baysal Üniversitesi Sosyal Bilimler Enstitüsü. Bolu.

Sazak-Pınar, E. (2008). Genel eğitim sınıflarında engelli olan ve olmayan öğrencilerin sosyal becerilerinin desteklenmesi. Abant İzzet Baysal Üniversitesi Sosyal Bilimler Enstitüsü Dergisi, 1(9) 171-187. https://doi.org/10.11616/AbantSbe.236

Serim-Yıldiz, B., \& Erdur-Baker, O. (2013). The Contemporary Fears of Turkish Children and Adolescents: Examining the Cultural Validity of Fear Survey Schedule for Children. The Journal of Genetic Psychology, 174(4), 345-365. https://doi.org/10.1080/00221325.2012.678420

Sevinçok, L. (2000). Sosyal Fobi ve Çekingen Kişilik Bozukluğu Arasındaki Tanısal Güçlükler. Psikiyatri Dünyası, 4(4), 3-7.

Steiner, H. (2007). Okul Çağl Çocuklarının Terapisi (H. Steiner ve I. D. Yalom, Ed.). Çev. Y. Ö. Şallı, İstanbul: Prestij Yayınları.

Sucuoğlu, B. (2006). Etkili kaynaştırma uygulamaları. Ankara: Ekinoks Yayınevi.

Sucuoğlu, B., \& Özokçu, O. (2005). Kaynaştırma öğrencilerinin sosyal becerilerinin değerlendirilmesi. Ankara Üniversitesi Eğitim Bilimleri Fakültesi Özel Eğitim Dergisi, 6(1) 41-57. https://doi.org/10.1501/Ozlegt_0000000086

Şahbaz, Ü. (2004). Kaynaştırma sinıflarına devam eden zihin engelli öğrencilerin sosyal kabul düzeylerin belirlenmesi. 13. Ulusal Özel Eğitim Kongresi'de sunulan sözlü bildiri. Ankara, Gazi Üniversitesi. Ankara: Kök Yayınevi.

Winnicott, D. W. (1998). Oyun ve Gerçeklik. İstanbul: Metis Yayınları.

Yıldırım, A., \& Şimşek, H. (2006). Sosyal bilimlerde nitel araştırma yöntemleri. Ankara: Seçkin Yayıncılık.

Yıldırım, T. (2006). Sosyal Kaygısı Yüksek Üniversite Öğrencilerine Uygulanan Kısa-Yoğun-Acil Psikoterapinin Etkililiği (Yayınlanmamış Doktora Tezi). Ankara: Hacettepe Üniversitesi.

Yıldız, C. (2008). Üniversite Öğrencilerinin Geçmişte Yaşadıkları Ayrılık Kaygısı İle Bağlanma Stilleri Arasındaki İlişkinin Incelenmesi Üzerine Bir Araştırma (Yayınlanmamış Yüksek Lisans Tezi). Selçuk Üniversitesi Sosyal Bilimler Enstitüsü, Konya.

Yörükoğlu, A. (1980). Çocuk Ruh Sağllğı. Ankara: Türkiye İş Bankası Kültür Yayınları.

Zulliger, H. (2000). Çocuklarımızın Korkuları (Çev.:K. Şipal). İstanbul: Cem Yayınevi. 


\section{Copyrights}

Copyright for this article is retained by the author(s), with first publication rights granted to the journal.

This is an open-access article distributed under the terms and conditions of the Creative Commons Attribution license (http://creativecommons.org/licenses/by/4.0/). 